\title{
A taxonomic study of bacteria isolated from grasses: a proposed new species Pseudomonas graminis sp. nov.
}

\author{
Undine Behrendt, ${ }^{1}$ Andreas Ulrich, ${ }^{2}$ Peter Schumann, ${ }^{3}$ Wilfried Erler, ${ }^{4}$ \\ Jutta Burghardt ${ }^{5}$ and Wolfgang Seyfarth ${ }^{2}$
}

\begin{abstract}
Author for correspondence: Undine Behrendt. Tel: +4933237 849357. Fax: +4933237849249. e-mail: ubehrendt@zalf.de
\end{abstract}

1,2 Centre for Agricultural Landscape and Land Use Research (ZALF), Institute of Microbial Ecology and Soil Biology, Gutshof 7, D 14641, Paulinenaue ${ }^{1}$, and Müncheberg², Germany

3,5 Deutsche Sammlung von Mikroorganismen und Zellkulturen, Jena ${ }^{3}$, and Braunschweig 5 , Germany

4 Federal Institute for Health Protection of Consumers and Veterinary Medicine, Jena Branch, Bacterial Animal Diseases and Zoonoses Control, Jena, Germany

\begin{abstract}
The taxonomic position of a yellow-pigmented group of bacteria, isolated from the phyllosphere of grasses was investigated. Results obtained from restriction analysis of amplified 165 rDNA with seven endonucleases (Cfol, Haell, Alul, Hinfl, Mspl, Sau3A and ScrFI) showed identical restriction patterns for each enzyme of all isolates studied, which suggests that all strains belong to the same species. The grass isolates displayed the characteristics of the genus Pseudomonas. They were Gram-negative, aerobic and rod-shaped with polar flagella. Isolates were catalase-positive and oxidase-negative, and unable to oxidize or ferment glucose with the production of acid. The isolates did not reduce nitrate to nitrite but were able to utilize a wide range of compounds individually as a sole carbon source, with preference being given to the utilization of monosaccharides. The disaccharides tested were not utilized as substrates. The DNA base compositions of the tested strains ranged from 60 to $61 \mathrm{~mol} \% \mathrm{G}+\mathrm{C}$. The major isoprenoid quinone of each was ubiquinone Q-9 and hydroxy fatty acids were represented by 3hydroxydodecanoic acid and 2-hydroxydodecanoic acid. Comparison of 165 rDNA sequences showed that the bacteria were members of the genus Pseudomonas, with similarity values between 91.5 and $97.7 \%$. DNA-DNA hybridization studies with closely related neighbours revealed a low level of homology $(<27 \%)$, indicating that the isolates represent an individual species. On the basis of phenotypic and phylogenetic analyses a new species, Pseudomonas graminis sp. nov. (type strain DSM 11363'), is proposed.
\end{abstract}

Keywords: Pseudomonas graminis sp. nov., plant-associated, phenotypic and phylogenetic analysis

\section{INTRODUCTION}

Characterization of community members are a requisite step for ecological studies of bacterial populations in the phyllosphere of plants. Frequently, identification to the level of species is difficult due to the paucity of information on those phyllosphere bacteria that are neither phytopathogenic nor related to bacteria of medical interest (Hirano \& Upper, 1992). Thus, recent ecological studies of microbial populations associated with various plants based on phenotypic features revealed groups of bacteria that were not

The EMBL accession number for the 165 rDNA sequence from Pseudomonas graminis DSM $11363^{\top}$ reported in this paper is Y11150. affiliated to known species (Ercolani, 1991; Legard et al., 1994; Thompson et al., 1993).

Investigations of bacterial community structure on grasses posed the same problems (Behrendt et al., 1997). An unknown group of yellow-pigmented strains was isolated during the whole vegetative period constituting an integral part of the Gram-negative population, with $10^{6}-10^{8}$ c.f.u. (g fresh material) ${ }^{-1}$. Yellowpigmented strains are common in the phyllosphere of plants and belong mainly to the genera Pantoea, Xanthomonas, Sphingomonas and Pseudomonas (Rudolph et al., 1990). On the basis of conventional physiological and morphological tests, it was not possible in those studies to assign the isolated group of strains to a genus or species. Phenotypic properties 
suggested that they were members of the genus Pseudomonas, but affiliation was not certain since the description of the genus Pseudomonas is too broad (Holt et al., 1994; Palleroni, 1991a).

The present study was undertaken to clarify the taxonomic position of this grass-associated bacterial group. Nineteen strains were selected randomly and extensively characterized by morphological, physiological and chemotaxonomic tests. Analysis of $16 \mathrm{~S}$ rDNA sequences and DNA-DNA hybridization studies were also performed to study phylogenetic relationships.

\section{METHODS}

Bacterial strains and cultivation. The bacterial strains examined in this study were isolated from grasses as described previously (Behrendt et al., 1997). One of the isolates (P 294/08) is deposited at the DSMZ (Deutsche Sammlung von Mikroorganismen und Zellkulturen, Braunschweig, Germany) as DSM $11363^{\mathrm{T}}$. The type strains of Sphingomonas paucimobilis, Sphingomonas parapaucimobilis, Pseudomonas mendocina and a Xanthomonas campestris strain were used for a comparison of some phenotypic characteristics. The histories and corresponding numbers of the bacteria are listed in Table 1. In general, all strains were cultured on nutrient agar II (Merck) supplemented with $1.5 \mathrm{~g}$ yeast extract $1^{-1}$ and $5.0 \mathrm{~g}$ glucose $1^{-1}$ at $25^{\circ} \mathrm{C}$ unless otherwise stated. Stocks of all cultures were maintained at $-81^{\circ} \mathrm{C}$ in nutrient broth II (SIFIN) containing $40 \%$ glycerol.

Morphological and physiological tests. Cell morphology was determined on cultures grown for $24-48 \mathrm{~h}$. Cultures grown in nutrient broth at 15,20 and $30^{\circ} \mathrm{C}$ were examined microscopically for evidence of motility. Staining of flagella was performed using the method of Rudolph \& Marvidis (1990). The Gram reaction was determined by three tests: classical staining procedure as described by Süßmuth $e t$ al. (1987), the rapid KOH string test (Ryu, 1938) and by presence of $\mathrm{L}$-alanine aminopeptidase tested using Bactident test strips (Merck).

Production of oxidase was assayed on an early growth-phase culture with the aid of Bactident oxidase test strips (Merck) and the activity of catalase was tested by suspending a loopful of cells in a $10 \%(\mathrm{v} / \mathrm{v}) \mathrm{H}_{2} \mathrm{O}_{2}$ solution. The ability to oxidize and ferment glucose was examined using the method described by Hugh \& Leifson (1953). Levan formation was tested on nutrient agar supplemented with $5 \%$ sucrose. Production of a fluorescent pigment was tested on King medium B (King et al., 1954). The method of Thornley (1960) was used to determine the presence of arginine dihydrolase, but was modified by covering the inoculated broth with sterile mineral oil (BioMérieux). Casein hydrolysis was assayed as described by Smibert \& Krieg (1994). Denitrification was determined as described by Azegami et al. (1987). DNase activity was tested on DNase agar (BioMérieux) by pouring $1 \mathrm{M} \mathrm{HCl}$ onto the incubated plates. Haemolysis was tested for on Merckoplate blood agar (6.5\% sheep blood) from Merck.

Utilization of carbon sources was detected by using the BIOLOG identification system. Each strain of the grass isolates was tested three times with GN plates (BIOLOG) according to the manufacturer's recommendations. Additionally, API 20NE and API 20E tests (BioMérieux) were used to determine physiological and biochemical characteristics.

For pigment analysis, strains to be tested were grown for $3 \mathrm{~d}$. Approximately $150 \mu \mathrm{l}$ aggregated cells were scraped from the agar surface and placed in test tubes. Methanol $(3 \mathrm{ml})$ was added and the mixture incubated at $50^{\circ} \mathrm{C}$ for $5 \mathrm{~min}$ to extract methanol-soluble pigments. After centrifugation, the absorbance of the supernatant was examined using a UV/visible spectrophotometer (Uvikon 930) with methanol as a blank. The methanol extract was also examined by TLC (Schaad \& Stall, 1994).

Determination of chemotaxonomic characteristics. For analysis of methylated fatty acids the strains were grown at $28^{\circ} \mathrm{C}$ on Trypticase Soy agar (Merck). After $24 \mathrm{~h}$ growth approximately $50 \mathrm{mg}$ (wet wt) of cells was harvested from the most dilute quadrant exhibiting confluent growth. Fatty acid methyl esters (FAMEs) were extracted and prepared by the method described by Stead (1988).

FAMEs were separated by gas chromatography and identified by mass spectrometric analysis (Saturn $3 \mathrm{Fa}$. Varian, Walnut Creek Californian; equipped with an autosampler 8200). Separation of FAMEs was carried out on a $30 \mathrm{~m}$ DB-5MS column $(0.25 \mathrm{~mm}$ inner diameter and $0.25 \mu \mathrm{m}$ film thickness). The column oven temperature was maintained at $100{ }^{\circ} \mathrm{C}$ for $3 \mathrm{~min}$ and then increased by $4^{\circ} \mathrm{C} \mathrm{min}-1$ to $250^{\circ} \mathrm{C}$, followed by $10^{\circ} \mathrm{C} \mathrm{min}^{-1}$ until $290^{\circ} \mathrm{C}$ was reached, where the temperature was maintained for $6 \mathrm{~min}$. The injector temperature was $260^{\circ} \mathrm{C}$. The transfer line was kept at $240^{\circ} \mathrm{C}$ and the iontrap at $180^{\circ} \mathrm{C}$. The carrier gas was helium. One microlitre of the FAME preparation in tertiary methyl butyl ether/methanol solution $(10: 1 \mathrm{v} / \mathrm{v})$ was injected using an autosampler.

The cells used for ubiquinone analysis and DNA extraction were obtained by cultivation at $28^{\circ} \mathrm{C}$ for $48 \mathrm{~h}(24 \mathrm{~h}$ for ubiquinones) in $100 \mathrm{ml}$ flasks containing $20 \mathrm{ml}$ medium 79 (Prauser \& Falta, 1968) shaken at 220 r.p.m. DNA was isolated and its $\mathrm{G}+\mathrm{C}$ content determined by HPLC as described by Martin et al. (1997). Ubiquinones were extracted according to the method described by Tindall (1990) and separated by HPLC as described previously (Groth et $a l ., 1996)$. They were identified by mass spectrometry using a model GCMS-QP2000 mass spectrometer (Shimadzu) fitted with a direct sample inlet system QP 2000 DI.

PCR and restriction analysis of 165 rDNA fragments. For template preparation, single colonies grown on solid medium were picked off, resuspended in $20 \mu 125 \mathrm{mM} \mathrm{NaOH}$, $0.25 \%$ SDS and heated for $15 \mathrm{~min}$ at $95^{\circ} \mathrm{C}$. From this lysate $0 \cdot 2 \mu \mathrm{l}$ was directly used for PCR without further purification. Using primers fD1 and rD1 (Weisburg et al., 1991), almost the complete 16S rDNA could be amplified. PCR was performed as described by Ulrich \& Müller (1998). PCR products $(2-8 \mu \mathrm{l})$ were digested with each of the following enzymes: CfoI, HaeIII, AluI, HinfI, MspI, Sau3A and ScrFI (Boehringer, Mannheim and New England Biolabs). To detect small differences between bands, the DNA fragments were separated on 2-3.5\% Metaphor agarose gels (FMC Bioproducts), depending on the fragment sizes to be distinguished.

$16 S$ rDNA sequence determination and analysis. The PCR product of the isolate $P$ 294/08 was purified by using the QIAquick PCR purification kit (Qiagen) and digested with 
Table 1. Bacterial strains used in this study

\begin{tabular}{|c|c|c|c|c|}
\hline Species/ isolate & DSM no.* & Other no. $\dagger$ & Source & $\begin{array}{l}\text { Date of } \\
\text { isolation }\end{array}$ \\
\hline P $200 / 02 \ddagger$ & & & Bulked sample of grasses§ & $20 / 04 / 93$ \\
\hline P $217 / 01 \ddagger$ & & & Bulked sample of grasses§ & $04 / 05 / 93$ \\
\hline P $226 / 02 \ddagger$ & & & Bulked sample of grasses $§$ & $11 / 05 / 93$ \\
\hline P 257/01† & & & Bulked sample of grasses§ & $25 / 05 / 93$ \\
\hline P $259 / 20 \ddagger$ & & & Bulked sample of grasses $\S$ & $25 / 05 / 93$ \\
\hline P 265/08t & & & Bulked sample of grasses§ & $01 / 06 / 93$ \\
\hline P $265 / 09 \ddagger$ & & & Bulked sample of grasses§ & $01 / 06 / 93$ \\
\hline P $274 / 03 \ddagger$ & & & Bulked sample of grasses§ & $08 / 06 / 93$ \\
\hline P $275 / 05 \ddagger$ & & & Bulked sample of grasses§ & $08 / 06 / 93$ \\
\hline P $278 / 03 \ddagger$ & & & Bulked sample of grasses§ & $08 / 06 / 93$ \\
\hline P $290 / 01 \ddagger$ & & & Bulked sample of grasses§ & $22 / 06 / 93$ \\
\hline P $294 / 05 \ddagger$ & & & Bulked sample of grasses§ & $22 / 06 / 93$ \\
\hline P $294 / 08 \ddagger$ & $11363^{\mathrm{T}}$ & & Bulked sample of grasses§ & $22 / 06 / 93$ \\
\hline P $312 / 01 \ddagger$ & & & Bulked sample of grasses§ & $15 / 06 / 93$ \\
\hline P $334 / 03 \ddagger$ & & & Bulked sample of grasses§ & $29 / 06 / 93$ \\
\hline P $350 / 05 \ddagger$ & & & Bulked sample of grasses $§$ & $06 / 07 / 93$ \\
\hline P $365 / 07 \ddagger$ & & & Bulked sample of grasses $\S$ & $13 / 07 / 93$ \\
\hline P $368 / 02 \ddagger$ & & & Bulked sample of grasses§ & $13 / 07 / 93$ \\
\hline P $375 / 03 \ddagger$ & & & Bulked sample of grasses§ & $13 / 07 / 93$ \\
\hline Pseudomonas agarici & $11810^{\mathrm{T}}$ & ATCC $25941^{\mathrm{T}}$ & Mushroom & \\
\hline Pseudomonas mendocina & $50017^{\mathrm{T}}$ & ATCC $25411^{\mathrm{T}}$ & Soil & \\
\hline Pseudomonas oryzihabitans & $6835^{T}$ & $\begin{array}{l}\text { ATCC } 43272^{\mathrm{T}} \\
\text { IAM } 1568^{\mathrm{T}}, \mathrm{JCM} 2952^{\mathrm{T}}\end{array}$ & Rice paddy & \\
\hline Pseudomonas putida & 6899 & & Unknown & \\
\hline Sphingomonas parapaucimobilis & $7463^{\mathrm{T}}$ & JCM7510 & Urine & \\
\hline Sphingomonas paucimobilis & $1098^{\mathrm{T}}$ & $\begin{array}{l}\text { ATCC } 29837^{\mathrm{T}}, \\
\text { NCTC } 11030^{\mathrm{T}}\end{array}$ & Hospital respirator & \\
\hline Xanthomonas campestris & 1050 & $\begin{array}{l}\text { ICPB XC } 135, \\
\text { NCPPB } 1929 \\
\text { PDDCC } 12\end{array}$ & Unknown & \\
\hline
\end{tabular}

*DSM, Deutsche Sammlung von Mikroorganismen und Zellkulturen.

$\dagger$ ATCC, American Type Culture Collection, Manassas, VA; IAM, Institute of Applied Microbiology, University of Tokyo, Bunkyoko, Tokyo, Japan; ICPB, International Collection of Phytopathogenic Bacteria, Davis, CA, USA; JCM, Japan Collection of Microorganisms, Institute of Physical and Chemical Research, Saitama, Japan; NCPPB, National Collection of Plant Pathogenic Bacteria, Plant Pathology Laboratory, Harpenden, UK; NCTC, National Collection of Type Cultures, Central Public Health Laboratory, London, UK; PDDCC, Plant Division Culture Collection, New Zealand Department of Scientific and Industrial Research, Auckland, New Zealand.

$\ddagger$ Number of culture in the collection at the Institute of Microbial Ecology and Soil Biology, Centre for Agricultural Landscape and Land Use Research Müncheberg (ZALF), Paulinenaue, Germany.

$\S$ Poa sp., Festuca sp., Elytrigia repens.

HaeIII, AluI and SmaI (Boehringer Mannheim). The PCR product and its restriction fragments were cloned and sequenced using fluorescent standard M13 primers. Sequencing of both strands was carried out according to the manufacturer's instructions of the AutoRead sequencing kit on an ALF DNA Sequencer (Pharmacia). Fragments of 1183-1350 nt of the generated rDNA sequence and those of the reference strains were aligned by CLUSTAL method (LaserGene, DNASTAR). ARB software [version 2.5b (1997) Technical University of Munich] was used for Felsenstein distance calculations. Dissimilarities were presented in a neighbour-joining dendrogram (Saitou \& Nei, 1987).
165 rDNA sequence accession numbers. The accession numbers of the sequences used for comparison with the sequence of strain P 294/08 were as follows: Brevundimonas diminuta DSM 1635, X87274; Burkholderia cepacia DSM 50181, X87275; Comamonas testosteroni ATCC 11996 ${ }^{\mathrm{T}}$, M11224; Pseudomonas aeruginosa DSM 50071 ${ }^{\mathrm{T}}$, X06684; Pseudomonas agarici ATCC 25941 ${ }^{\mathrm{T}}$, D84005; Pseudomonas alcaligenes IAM 12411 ${ }^{\mathrm{T}}$, D84006; Pseudomonas amygdali ATCC $33614^{\mathrm{T}}$, D84007; Pseudomonas anguilliseptica NCIMB 1949 ${ }^{\mathrm{T}}$, X99540; Pseudomonas asplenii LMG $2137^{\mathrm{T}}$, Z76655; Pseudomonas avellanae P90, U49384; Pseudomonas azotoformans IAM 1603' ${ }^{\mathrm{T}}$, D84009; Pseudomonas balearica SP 1402 ${ }^{\mathrm{T}}$, U26418; Pseudomonas caricapapayae ATCC 
$33615^{\mathrm{T}}$, D84010; Pseudomonas chlororaphis IAM 12354 ${ }^{\mathrm{T}}$, D84011; Pseudomonas cichorii LMG 2162 ${ }^{\mathrm{T}}$, Z76658; Pseudomonas citronellolis DSM 50332 ${ }^{\mathrm{T}}$, Z76659; Pseudomonas corrugata ATCC 29736 ${ }^{\mathrm{T}}$, D84012; Pseudomonas flavescens NCPPB 3063 ${ }^{\mathrm{T}}$, U01916; Pseudomonas fluorescens IAM 12022 ${ }^{\mathrm{T}}$, D84013; Pseudomonas fragi IAM 12402, D84014; Pseudomonas fulva IAM 1529 ${ }^{\mathrm{T}}$, D84015; Pseudomonas lemoignei LMG 2207 ${ }^{\mathrm{T}}$, X92555; Pseudomonas luteola IAM 13000 ${ }^{\mathrm{T}}$, D84002; Pseudomonas marginalis LMG 2210 ${ }^{\mathrm{T}}$, Z76663; P. mendocina ATCC 25411 ${ }^{\mathrm{T}}$, M59154; Pseudomonas mucidolens IAM 12406 ${ }^{\mathrm{T}}$, D84017; Pseudomonas nitroreducens IAM 1439' ${ }^{\mathrm{T}}$, D84021; Pseudomonas oleovorans IAM 1508 ${ }^{\mathrm{T}}$, D84018; Pseudomonas oryzihabitans IAM 1568 , D84004; 'Pseudomonas pavonaceae' IAM 1155, D84019; Pseudomonas pseudoalcaligenes LMG $1225^{\mathrm{T}}$, Z76666; Pseudomonas putida DSM 6899, L37365; Pseudomonas resinovorans LMG 2274, Z76668; Pseudomonas rhodesiae CIP 104664 ${ }^{\mathrm{T}}$, AF064459; Pseudomonas stanieri NCIMB 2040, X92176; Pseudomonas straminea IAM $1598^{\mathrm{T}}$, D84023; Pseudomonas stutzeri CCUG 11256 ${ }^{\mathrm{T}}$, U26262; Pseudomonas synxantha IAM 12356 ${ }^{\mathrm{T}}$, D84025; Pseudomonas syringae ATCC 19310 ${ }^{\mathrm{T}}$, D84026; Pseudomonas taetrolens IAM 1653' ${ }^{\mathrm{T}}$, D84027; Pseudomonas tolaasii ATCC 33618 ${ }^{\mathrm{T}}$, D84028; Pseudomonas viridiflava LMG 2352 ${ }^{\mathrm{T}}$, Z76671; Ralstonia solanacearum R633, U28230; Sphingomonas parapaucimobilis JCM $7510^{\mathrm{T}}$, X72721; Sphingomonas paucimobilis ATCC $29837^{\mathrm{T}}$, U37337; Stenotrophomonas maltophilia ATCC 33913, M59158; $X$. campestris LMG 568$\mathrm{T}, \mathrm{X} 95917$. The nucleotide sequence data for the isolate $\mathrm{P}$ 294/08 has been deposited in the EMBL nucleotide sequence database under the accession number Y 11150.

DNA-DNA hybridization analysis. DNA-DNA homology was tested between the isolates P 265/09 and P 200/02, and also between P 294/08 (DSM 11363') and P 294/05, Pseudomonas oryzihabitans, Pseudomonas putida or Pseudomonas agarici, according to the method described by Martin et al. (1997).

\section{RESULTS}

\section{Morphological, physiological and biochemical characteristics}

All of the grass isolates studied were Gram-negative, aerobic, non spore-forming, rod-shaped organisms
$(0 \cdot 5-1 \cdot 0 \times 3 \cdot 5-5 \cdot 0 \mu \mathrm{m})$ that usually occurred as single cells. The cells were motile and possessed one polar flagellum, but motility depended on the temperature of incubation. They were motile when grown at 15 and $20^{\circ} \mathrm{C}$ but not at $30^{\circ} \mathrm{C}$.

The optimum growth temperature was $25^{\circ} \mathrm{C}$. Cells did not grow at $42{ }^{\circ} \mathrm{C}$ but growth was slow at $4{ }^{\circ} \mathrm{C}$. The cells did not produce a fluorescent pigment. Colonies that were $24 \mathrm{~h}$ old were translucent, pale yellow and convex with an entire margin. Older colonies became deep yellow. Methanol-soluble pigments extracted from whole cells of each of the grass-associated isolates, as well as from the reference strains, showed that the absorbance spectra were identical to those detected for Sphingomonas paucimobilis and Sphingomonas parapaucimobilis. Similar spectra obtained for the Sphingomonas species have already been described by Holmes et al. (1977) and Pollock (1993). A representative spectrum for each species included a major peak at $448-450 \mathrm{~nm}$, a secondary peak at $474-476 \mathrm{~nm}$ and a slight inflection between about 415 and $430 \mathrm{~nm}$. In contrast, the pigment in the methanol extract from $P$. mendocina gave only one peak, at $431 \mathrm{~nm}$. $X$. campestris showed a major peak at $443 \mathrm{~nm}$ and two slight inflections at $417 \mathrm{~nm}$ and $468 \mathrm{~nm}$, similar to the results of Starr et al. (1977). However, TLC of the methanol-soluble pigments showed different results for the $R_{F}$ values of Sphingomonas species $(0 \cdot 85)$ in comparison to the grass-associated isolates $(0.93)$, which indicated differences in the composition of pigments.

The rapid $\mathrm{KOH}$ Gram test for all grass isolates was negative. This result is in agreement with traditional Gram-stain results as well as with those for the presence of L-alanine aminopeptidase. Physiological tests which were different between the grass isolates are shown in Table 2. All strains gave positive results for catalase, aesculin hydrolysis, utilization of citrate and growth on MacConkey agar. The following characteristics were negative for all strains: fermentation and oxidation of glucose; acid production from inositol,

Table 2. Physiological tests showing differing results among the 19 strains of grass isolates tested

\begin{tabular}{|c|c|c|c|}
\hline Test & $\begin{array}{l}\text { Results of P 294/08 } \\
\quad \text { (DSM 11363) }\end{array}$ & $\begin{array}{l}\text { No. strains } \\
(+/-)\end{array}$ & $\begin{array}{c}\text { Strains showing the less common } \\
\text { response }\end{array}$ \\
\hline Hydrolysis of gelatin & + & $15 / 4$ & P 226/02; P 257/01; P 265/08; P 312/01 \\
\hline Casein hydrolysis & + & $13 / 6$ & $\begin{array}{l}\text { P } 226 / 02 ; \text { P } 257 / 01 ; \text { P } 265 / 08 \\
\text { P } 274 / 03 ; \text { P } 278 / 03 ; \text { P } 334 / 03\end{array}$ \\
\hline \multicolumn{4}{|c|}{ Oxidative acid production from: } \\
\hline Melibiose & + & $14 / 5$ & $\begin{array}{l}\text { P } 226 / 02 ; \text { P } 265 / 08 ; \text { P } 265 / 09 ; \\
\text { P } 350 / 05 ; \text { P } 365 / 07\end{array}$ \\
\hline Rhamnose & - & $2 / 16$ & P $259 / 02 ;$ P $278 / 03$ \\
\hline Arabinose & + & $16 / 3$ & P $265 / 09 ;$ P $365 / 07 ;$ P 375/03 \\
\hline
\end{tabular}


sorbitol, sucrose and amygdalin; formation of levan from sucrose; oxidase reaction; reduction of nitrate to nitrite; denitrification; arginine dihydrolase; lysine decarboxylase; ornithine decarboxylase; tryptophan desaminase; DNase; urease; $\beta$-haemolysis of sheep blood; $\beta$-galactosidase; Voges-Proskauer reaction; indole production; and $\mathrm{H}_{2} \mathrm{~S}$ production from sodium thiosulphate.

Characterization of the isolates with the API 20NE system, created for the identification of non-enteric Gram-negative rods, resulted in a reaction profile which indicated an affiliation to $P$. chlororaphis. According to the appropriate API analytical profile index, the identification quality amounted to $98.5 \%$, suggesting 'good identification'. The interpretation of results obtained with the BIOLOG Microbial Identification System suggests an identification as $P$. tolaasii at a similarity index between 0.520 and 0.646 , which is also regarded as 'good identification'.

Utilization of different carbon sources estimated with the BIOLOG system are shown in Table 3. From a nutritional standpoint, the grass isolates had a broad spectrum. Many different compounds served as a sole source of carbon and energy. Preference in the utilization of carbohydrates tested was given to monomeric sugars, whilst none of the disaccharides tested were used as a substrate.

In general, the phenotypic properties of the grassassociated isolates studied were relatively homogeneous. Only a few characteristics were different between the tested strains.

\section{Restriction analysis of amplified 16S rDNA and DNA-DNA hybridization studies among selected isolates}

To analyse the heterogeneity of the 19 isolates in relation to their 16S rRNA genes, total DNA was amplified with the primers described by Weisburg et al. (1991). All strains showed a single band of about $1500 \mathrm{bp}$. Digestion of these PCR products with the seven endonucleases used (CfoI, HaeIII, AluI, HinfI, $M s p I, S a u 3 A$ and $S c r F I$; a total of 36 restriction sites analysed) resulted in identical restriction patterns per enzyme for all 19 isolates (data not shown).

DNA-DNA hybridization analysis between strains $P$ $294 / 08$ and $\mathrm{P} 294 / 05$ revealed a homology value of $95.9 \%$, and $92.2 \%$ between $P 265 / 09$ and $P$ 200/02. These results strongly support an affiliation of all grass isolates to the same species.

\section{Chemical characteristics}

The cellular fatty acid compositions of the grass isolates are shown in Table 4. In all strains, hexadecanoic acid (16:0), hexadecenoic acid (16:1) and octadecenoic acid (18:1) were the major non-polar fatty acids, whilst the hydroxy fatty acids were represented by 3-hydroxydodecanoic acid (3-OH12:0) and 2-hydroxydodecanoic acid (2-OH12:0).

On the basis of the restriction analysis of the amplified $16 \mathrm{~S}$ rDNA, five strains were selected for analysis of their DNA base composition and for characterization of ubiquinones. As shown in Table 5, the tested isolates contained ubiquinone $\mathrm{Q}_{9}$ and minor amounts of ubiquinones $\mathrm{Q}_{8}$ and $\mathrm{Q}_{7}$. The DNA base composition ranged from 60 to $61 \mathrm{~mol} \% \mathrm{G}+\mathrm{C}$.

\section{Phylogenetic analysis}

The 16S rDNA sequence, corresponding to nucleotides 28-1524 of the Escherichia coli sequence, was determined for the isolate P $294 / 08\left(D S M 11363^{\mathrm{T}}\right)$. The corresponding DNA sequence has a length of $1492 \mathrm{bp}$, and was compared with 16S rDNA of 47 reference strains. The strains examined comprise species of the genus Pseudomonas, representing the Palleroni rRNA group I, species of Burkholderia and Ralstonia belonging to rRNA group II, and Comamonas, Brevundimonas and Stenotrophomonas, which are representatives of the rRNA groups III, IV and V, respectively (Palleroni, 1991a). Additionally, species of Xanthomonas and Sphingomonas were included since they belong to phenotypically similar taxa. The 16S rDNA sequence of the grass isolate showed a high level of homology to the majority of members of the genus Pseudomonas. Similarity values shown in Table 6 are based on data from a $1360 \mathrm{bp}$ alignment. Levels of similarity to P $294 / 08$ ranged from $64.1 \%$ to $97 \cdot 7 \%$ within the genus Pseudomonas. The best matches were found to the 16S rDNA sequence of $P$. oryzihabitans $(97.7 \%)$, P putida $(97.6 \%)$, P. agarici $(97.2 \%)$, and ' $P$. pavonaceae' $(97 \cdot 1 \%)$. In Fig. 1 an unrooted neighbour-joining dendrogram is shown for a selection of Pseudomonas species and some representatives of the genera mentioned above. It clearly indicates that $P$ 294/08 is a member of the genus Pseudomonas. Phylogenetic analysis using the parsimony algorithm revealed a similar clustering, only the distance between Pseudomonas and the other genera was less distinct (data not shown).

Characterization of phylogenetic relationships to species level by $16 \mathrm{~S}$ rDNA analysis is restricted at similarity values higher than $97 \%$ (Stackebrandt \& Goebel, 1994). Thus, DNA-DNA homology was examined between P 294/08 and $P$. oryzihabitans, $P$. putida or $P$. agarici. ' $P$. pavonaceae' was excluded from this study since it must be classified as an atypical strain of an invalid species (Anzai et al., 1997).

The results of DNA-DNA reassociation revealed a homology value between strain $P$ 294/08 and $P$. oryzihabitans of $18.6 \%$, P $294 / 08$ and $P$. putida, $26.2 \%$ and $P$ 294/08 and $P$. agarici, $14.0 \%$ respectively. This low level of DNA homology clearly indicates a segregation of the isolate as an independent species. 
Table 3. Utilization of carbon sources by grass isolates estimated with the BIOLOG system

A total of 19 strains were tested in triplicate.

\begin{tabular}{|c|c|c|c|c|c|}
\hline \multirow[t]{2}{*}{ Positive reaction } & \multirow[t]{2}{*}{ Negative reaction } & \multicolumn{4}{|c|}{ Different reactions between strains* } \\
\hline & & Carbon source & $+\dagger$ & $-\dagger$ & $+1-\ddagger$ \\
\hline Adonitol & $N$-Acetyl-D-galactosamine & D-Psicose & $17 \S$ & 0 & 2 \\
\hline L-Arabinose & $N$-Acetyl-D-glucosamine & Turanose & 2 & 14 & 3 \\
\hline D-Arabitol & Cellobiose & Xylitol & 14 & 1 & 4 \\
\hline D-Fructose & i-Erythritol & Acetic acid & 15 & 3 & 1 \\
\hline L-Fucose & Gentiobiose & $\alpha$-Hydroxybutyric acid & 9 & 7 & 3 \\
\hline D-Galactose & $\alpha$-D-Lactose & $\alpha$-Ketobutyric acid & 9 & 8 & 2 \\
\hline$\alpha$-D-Glucose & Lactulose & $\alpha$-Ketovaleric acid & 10 & 7 & 2 \\
\hline$m$-Inositol & D-Melibiose & Propionic acid & 11 & 5 & 3 \\
\hline D-Mannitol & $\beta$-Methyl-D-glucoside & Alaninamide & 7 & 11 & 1 \\
\hline D-Mannose & D-Raffinose & Glycyl-L-glutamic acid & 12 & 3 & 4 \\
\hline D-Sorbitol & L-Rhamnose & Hydroxy-L-proline & 11 & 6 & 2 \\
\hline Methylpyruvate & Sucrose & L-Leucine & 12 & 3 & 4 \\
\hline Monomethyl succinate & D-Trehalose & L-Ornithine & 6 & 12 & 1 \\
\hline cis-Aconitic acid & $\gamma$-Hydroxybutyric acid & D-Serine & 16 & 0 & 3 \\
\hline Citric acid & $p$-Hydroxyphenylacetic acid & L-Serine & 16 & 1 & 2 \\
\hline Formic acid & Quinic acid & L-Threonine & 15 & 1 & 3 \\
\hline D-Galactonic acid & Sebacic acid & D,L-Carnitine & 17 & 1 & 1 \\
\hline D-Galacturonic acid & Glycyl-L-aspartic acid & $D, L-\alpha-$ Glycerolphosphate & 14 & 5 & 0 \\
\hline D-Gluconic acid & L-Phenylalanine & & & & \\
\hline D-Glucosaminic acid & Thymidine & & & & \\
\hline D-Glucuronic acid & Phenylethylamine & & & & \\
\hline$\beta$-Hydroxybutyric acid & Putrescine & & & & \\
\hline Itaconic acid & 2,3-Butanediol & & & & \\
\hline$\alpha$-Ketoglutaric acid & Glucose-1-phosphate & & & & \\
\hline D,L-Lactic acid & Glucose-6-phosphate & & & & \\
\hline Malonic acid & $\alpha$-Cyclodextrin & & & & \\
\hline D-Saccharic acid & Dextrin & & & & \\
\hline Succinic acid & Glycogen & & & & \\
\hline Bromosuccinic acid & Maltose & & & & \\
\hline Succinamic acid & & & & & \\
\hline Glucuronamide & & & & & \\
\hline D-Alanine & & & & & \\
\hline L-Alanine & & & & & \\
\hline L-Alanylglycine & & & & & \\
\hline L-Asparagine & & & & & \\
\hline L-Aspartic acid & & & & & \\
\hline L-Glutamic acid & & & & & \\
\hline L-Histidine & & & & & \\
\hline L-Proline & & & & & \\
\hline L-Pyroglutamic acid & & & & & \\
\hline$\gamma$-Aminobutyric acid & & & & & \\
\hline Urocanic acid & & & & & \\
\hline Inosine & & & & & \\
\hline Uridine & & & & & \\
\hline 2-Aminoethanol & & & & & \\
\hline Glycerol & & & & & \\
\hline Tween 40 & & & & & \\
\hline Tween 80 & & & & & \\
\hline
\end{tabular}

* For numbers in bold type, the group contained the strain P 294/08 (DSM 11363T).

$\dagger$ Number of strains which gave positive or negative results in triplicate experiments/strain.

$\ddagger$ Number of strains which gave variable results in the triplicate assays. 
Table 4. Cellular fatty acid composition of the grass isolates

\begin{tabular}{|c|c|c|c|c|c|c|c|c|}
\hline \multirow[t]{2}{*}{ Isolate } & \multicolumn{8}{|c|}{ Fatty acid composition (\%) } \\
\hline & $12: 0$ & 2-OH12:0 & 3-OH12:0 & $14: 1$ & $14: 0$ & $16: 1$ & $16: 0$ & $18: 1$ \\
\hline P $200 / 02^{*}$ & $2 \cdot 9$ & $0 \cdot 8$ & $2 \cdot 4$ & $0 \cdot 2$ & $0 \cdot 3$ & $57 \cdot 1$ & $27 \cdot 4$ & $8 \cdot 7$ \\
\hline P $217 / 01$ & $2 \cdot 0$ & 0.3 & 0.5 & $0 \cdot 1$ & $0 \cdot 3$ & $51 \cdot 6$ & $32 \cdot 1$ & $13 \cdot 2$ \\
\hline P 226/02 & $3 \cdot 4$ & 0.6 & $1 \cdot 3$ & 0.2 & & $53 \cdot 1$ & $27 \cdot 4$ & $14 \cdot 0$ \\
\hline P $257 / 01$ & $3 \cdot 3$ & $2 \cdot 3$ & $2 \cdot 6$ & 0.2 & $0 \cdot 2$ & $57 \cdot 8$ & $28 \cdot 1$ & $5 \cdot 4$ \\
\hline P $259 / 20$ & $2 \cdot 5$ & 0.4 & 0.9 & - & - & $51 \cdot 1$ & $29 \cdot 5$ & $15 \cdot 6$ \\
\hline P $265 / 08$ & - & 0.2 & 0.9 & - & - & $59 \cdot 9$ & $29 \cdot 3$ & $9 \cdot 6$ \\
\hline P 265/09 & $2 \cdot 1$ & $0 \cdot 3$ & $0 \cdot 8$ & - & $0 \cdot 2$ & $56 \cdot 5$ & $29 \cdot 7$ & $10 \cdot 4$ \\
\hline P 274/03 & $2 \cdot 4$ & 0.4 & $0 \cdot 7$ & - & $0 \cdot 2$ & $50 \cdot 1$ & $31 \cdot 7$ & $14 \cdot 5$ \\
\hline P $275 / 05$ & $2 \cdot 1$ & 0.5 & 0.6 & $0 \cdot 1$ & $0 \cdot 2$ & $60 \cdot 0$ & $31 \cdot 6$ & 4.9 \\
\hline P $278 / 03$ & $1 \cdot 0$ & $0 \cdot 2$ & $0 \cdot 4$ & - & - & $49 \cdot 9$ & $31 \cdot 0$ & $17 \cdot 6$ \\
\hline P 290/01 & $2 \cdot 7$ & $0 \cdot 7$ & 0.5 & $0 \cdot 2$ & - & $58 \cdot 0$ & $32 \cdot 8$ & $5 \cdot 0$ \\
\hline P 294/05 & $2 \cdot 0$ & $0 \cdot 2$ & 0.6 & - & - & $50 \cdot 7$ & $31 \cdot 8$ & $14 \cdot 7$ \\
\hline P 294/08 & 1.9 & $0 \cdot 2$ & 0.6 & - & - & $55 \cdot 6$ & $29 \cdot 8$ & 11.9 \\
\hline P $312 / 01$ & $3 \cdot 1$ & 0.5 & - & - & - & $50 \cdot 4$ & $29 \cdot 7$ & $16 \cdot 2$ \\
\hline P $334 / 03$ & 0.9 & $0 \cdot 1$ & - & - & - & $61 \cdot 2$ & $34 \cdot 3$ & $3 \cdot 5$ \\
\hline P $350 / 05$ & $2 \cdot 7$ & $0 \cdot 3$ & $0 \cdot 7$ & - & - & $51 \cdot 3$ & $31 \cdot 4$ & $13 \cdot 6$ \\
\hline P $365 / 07$ & $2 \cdot 4$ & 1.0 & $0 \cdot 8$ & - & $0 \cdot 2$ & $54 \cdot 3$ & $30 \cdot 1$ & $11 \cdot 1$ \\
\hline P $368 / 02$ & $3 \cdot 2$ & 0.4 & $0 \cdot 8$ & $0 \cdot 1$ & $0 \cdot 3$ & $52 \cdot 2$ & $29 \cdot 9$ & $13 \cdot 1$ \\
\hline P $375 / 03$ & - & $0 \cdot 1$ & 0.5 & - & - & $61 \cdot 4$ & $35 \cdot 5$ & $2 \cdot 4$ \\
\hline
\end{tabular}

*Also contains 0.2\% 15:0.

Table 5. DNA base composition of selected grass isolates and composition of ubiquinones

\begin{tabular}{|lcrrr|}
\hline Isolate & $\begin{array}{c}\text { G }+ \text { C content } \\
\text { (mol \%) }\end{array}$ & \multicolumn{3}{c|}{$\begin{array}{c}\text { Ubiquinone } \\
\text { (ratio of peak area) }\end{array}$} \\
\cline { 3 - 5 } & & $\mathbf{Q}_{9}$ & $\mathbf{Q}_{\mathbf{8}}$ & $\mathbf{Q}_{7}$ \\
\hline P 200/02 & 61 & 66 & 24 & 4 \\
P 265/08 & 60 & 83 & 3 & 4 \\
P 294/05 & 60 & 76 & 13 & 3 \\
P 294/08 & 60 & 86 & 9 & 3 \\
P 334/03 & 60 & 69 & 15 & 2 \\
\hline
\end{tabular}

\section{DISCUSSION}

The phenotypic characteristics of the studied grassassociated isolates were relatively homogeneous. Only a few features, which mainly concern the utilization of carbohydrates, were different between the tested strains (Tables 2, 3 and 4). These high similarities between the isolates suggest grouping as a single species. Furthermore, restriction analysis of amplified 16S rDNA and DNA-DNA reassociation studies strongly support the argument that all the strains investigated belong to the same species.

Based on this finding, chemotaxonomical classifications were focused on selected strains (Table 5). The tested isolates displayed $\mathrm{Q}_{9}$ as the major ubiquinone, similar to the Pseudomonas species of the Palleroni rRNA group I (Oyaizu \& Komagata, 1983). The determined $\mathrm{G}+\mathrm{C}$ content is also similar to that of members in this group (Palleroni, 1984). Physiological and morphological characteristics of the grass isolates match general phenotypic characteristics of the genus Pseudomonas (Palleroni, 1991a). However, the original genus Pseudomonas was a phylogenetically diverse assemblage of species, which could be divided into at least five distinct sub-groups based on rRNA homology data (Palleroni et al., 1973). As a result of polyphasic classifications of the different rRNA groups, most species belonging to rRNA groups II-V have been transferred to other genera (Palleroni \& Bradbury, 1993; Segers et al., 1994; Tamaoka et al., 1987; Willems et al., 1989, 1990; Yabuuchi et al., 1992), leaving group I as Pseudomonas sensu stricto (Palleroni, 1992), with P. aeruginosa as the type species of the genus.

For phylogenetic analysis of the strains studied, the 16S rDNA sequence determined from one of the isolates (P 294/08) was compared with the sequence of 47 reference strains representing the different rRNA groups of the original genus Pseudomonas, as well as phenotypically similar taxa. As shown in Fig. 1, the clear clustering to species of rRNA group I gives support to placing of the isolates within the genus Pseudomonas sensu stricto. The level of 16S rRNA homology between the grass isolate and the type species $(91.5 \%)$ was higher than the level between 
Table 6. Similarity values based on a comparison of $1340 \mathrm{nt}$ of the $16 \mathrm{~S}$ rRNA gene of the isolate P 294/08 and the corresponding sequences of proved Pseudomonas species

\begin{tabular}{|c|c|}
\hline & Pseudomonas species (\% similarity to P $294 / 08$ ) \\
\hline $\begin{array}{l}\text { Similarity group I: values below } \\
90 \%\end{array}$ & $\begin{array}{l}\text { P. echinoides }(75 \cdot 6)^{*}, \text { P. lemoignei }(77 \cdot 2), \\
\text { Pseudomonas stanieri }(64 \cdot 1), \text { P. syzygii }(70 \cdot 2) \dagger\end{array}$ \\
\hline $\begin{array}{l}\text { Similarity group II: values between } \\
90 \text { and } 97 \%\end{array}$ & 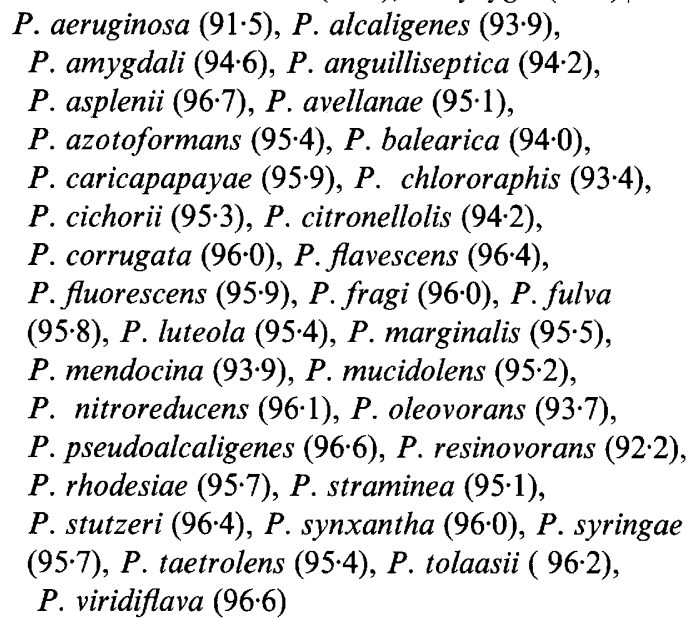 \\
\hline $\begin{array}{l}\text { Similarity group III: values above } \\
97 \%\end{array}$ & $\begin{array}{l}\text { P. agarici }(97 \cdot 2), \text { P. oryzihabitans }(97 \cdot 7) \\
\text { 'P. pavonaceae' }(97 \cdot 1), P . \text { putida }(97 \cdot 6)\end{array}$ \\
\hline
\end{tabular}

* Comparison of a $509 \mathrm{bp}$ sequence of the $16 \mathrm{~S}$ rRNA gene ( $E$. coli numbering $388-923)$. In this region, the similarity of $\mathrm{P} 294 / 08$ to group II and III species ranged from $89 \cdot 1 \%$ to $98 \cdot 5 \%$ and from 96.5 to $97.8 \%$, respectively. Therefore, $P$. echinoides was listed in group I.

$\uparrow$ Comparison of a 291 bp sequence of the 16S rRNA gene ( $E$. coli numbering 44-337). In this region, the similarity of $P 294 / 08$ to group II and III species ranged from 84.7 to $97.9 \%$ and from $97.2 \%$ to $97.6 \%$, respectively. Therefore, $P$. syzygii was listed in group I.

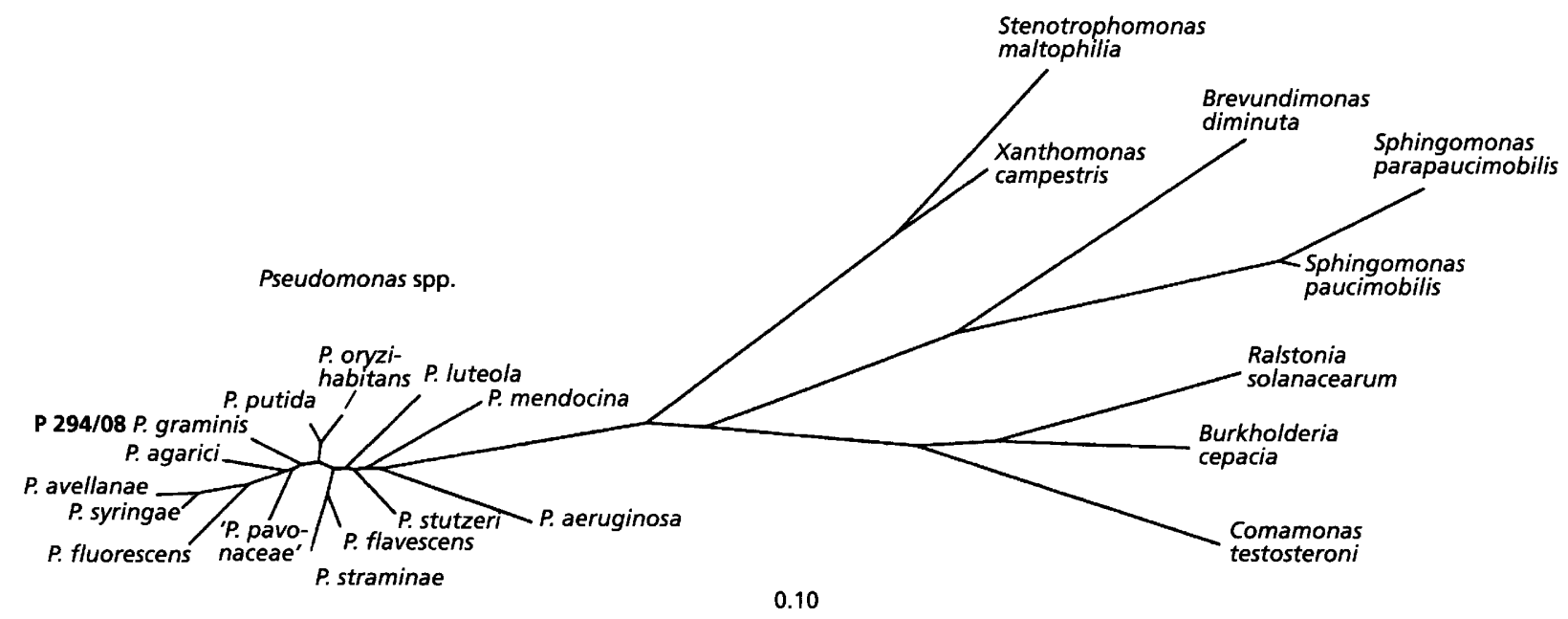

Fig. 1. Unrooted phylogenetic tree showing the relationship between strain $P$ 294/08 (P. graminis) and members of the genus Pseudomonas and some related genera. The tree was calculated from a dissimilarity matrix of a 1360 bp alignment (positions 50-1394 of E. coli numbering) using a neighbour-joining algorithm.

some accepted members of the genus, for example $P$. syringae $(90.2 \%)$ or $P$. fluorescens $(90.4 \%)$, and the type species $P$. aeruginosa.
The closest phylogenetically related species were $P$. oryzihabitans, $P$. putida, $P$. agarici, and ' $P$. pavonaceae', with similarity values higher than $97 \%$. How- 
Table 7. Differential characteristics of Pseudomonas graminis and phenotypically similar species

Data from this study and Gilardi (1991), Holmes et al. (1986), Holmes et al. (1987), Holt et al. (1994), Oyaizu \& Komagata (1983), Segers et al. (1994), Yabuuchi et al. (1990). NT, Not tested.

\begin{tabular}{|c|c|c|c|c|c|c|c|c|}
\hline Characteristic & $\begin{array}{c}\text { Pseudomonas } \\
\text { graminis }\end{array}$ & $\begin{array}{l}\text { Pseudomonas } \\
\text { mendocina }\end{array}$ & $\begin{array}{l}\text { Pseudomonas } \\
\text { oryzihabitans }\end{array}$ & $\begin{array}{c}\text { Pseudomonas } \\
\text { luteola }\end{array}$ & $\begin{array}{c}\text { Brevundimonas } \\
\text { vesicularis }\end{array}$ & $\begin{array}{c}\text { Sphingomonas } \\
\text { parapaucimobilis }\end{array}$ & $\begin{array}{l}\text { Sphingomonas } \\
\text { paucimobilis }\end{array}$ & $\begin{array}{c}\text { Xanthomonas } \\
\text { campestris }\end{array}$ \\
\hline Flagella & $\begin{array}{c}\text { Polar } \\
\text { monotrichous }\end{array}$ & $\begin{array}{c}\text { Polar } \\
\text { monotrichous* }\end{array}$ & $\begin{array}{c}\text { Polar } \\
\text { monotrichous or } \\
\text { non-motile }\end{array}$ & $\begin{array}{l}\text { Multitrichous } \\
\text { (10-12 flagella) }\end{array}$ & $\begin{array}{c}\text { Polar } \\
\text { monotrichous }\end{array}$ & $\begin{array}{c}\text { Polar } \\
\text { monotrichous }\end{array}$ & $\begin{array}{c}\text { Polar } \\
\text { monotrichous }\end{array}$ & $\begin{array}{c}\text { Polar } \\
\text { monotrichous }\end{array}$ \\
\hline Growth at $4{ }^{\circ} \mathrm{C}$ & + & - & - & - & - & - & - & - \\
\hline Growth at $42{ }^{\circ} \mathrm{C}$ & - & + & - & + & - & - & - & - \\
\hline Oxidation of glucose & - & + & + & + & - & + & + & + \\
\hline Growth on MacConkey agar & + & + & + & + & + & - & - & - \\
\hline Oxidase reaction & - & + & - & - & + & - & - & - \\
\hline Arginine dihydrolase & - & + & - & + & - & - & - & - \\
\hline Aesculin hydrolysis & + & - & - & + & + & + & + & + \\
\hline Gelatin hydrolysis & variable & - & - & + & - & - & + & + \\
\hline Starch hydrolysis & - & - & - & - & - & + & + & + \\
\hline DNase & - & - & NT & NT & - & - & + & + \\
\hline Lipase - Tween 80 & + & + & - & - & - & + & + & + \\
\hline$\beta$-Galactosidase & - & - & - & + & - & + & + & + \\
\hline \multirow[t]{5}{*}{ Major cellular hydroxy fatty acid(s) } & 2-OH12:0 & 3-OH10:0 & 3-OH10:0† & $3-\mathrm{OH} 10: 0 \dagger$ & $3-\mathrm{OH} 12: 0$ & 2-OH $14: 0$ & 2-OH14:0 & 3-OH10:0 \\
\hline & $3-\mathrm{OH} 12: 0$ & 2-OH $12: 0$ & 2-OH12:0 & 2-OH12:0 & 3-OH14:0 & & & 3-OH12:0 \\
\hline & & 3-OH12:0 & $3-\mathrm{OH} 12: 0$ & 3-OH12:0 & & & & 2-OH13:0 \\
\hline & & & & & & & & 3-OHi11:0 \\
\hline & & & & & & & & 3-OHi13:0 \\
\hline
\end{tabular}

* Lateral flagella may also be produced under certain conditions (Holt et al., 1994).

$\dagger$ Data from the MIS system (Microbial ID).

ever, 'P. pavonaceae' (IAM 1155) represents an invalid species with contradictory data. Studies by Van Landschoot et al. (1986) revealed that the species ' $P$. pavonaceae' (NCTC 10693, CCEB 533) belongs to the Acinetobacter rRNA branch. Therefore, the strain must be characterized as atypical and thus not representative of its species.

At homologies higher than $97 \%$, the use of $16 \mathrm{~S}$ rDNA sequence analysis for the characterization of relationships between species is limited (Stackebrandt \& Goebel, 1994). For this reason, DNA-DNA hybridization experiments were performed to clarify the affiliation of the grass isolates at species level. The DNA reassociation values that were found to be lower than $26 \%$ between the grass isolate and the immediate phylogenetic neighbours unequivocally demonstrated that the grass isolates represent an individual species in comparison to the analysed taxa.

Phenotypic features are also able to demarcate the isolates from phylogenetically related species. Most members of rRNA group I are characterized by the production of fluorescent pigments. Thus, the studied grass isolates can easily be separated from them by the presence of a yellow pigment and the absence of fluorescence. On this basis they can be distinguished from the closely related species $P$. putida and $P$. agarici. $P$. flavescens and $P$. straminea are yellow-pigmented species that are also able to produce fluorescent pigments. Additional biochemical properties, such as a positive oxidase reaction of both taxa, the production of $\mathrm{H}_{2} \mathrm{~S}$ and acid from glucose, as determined for $P$. straminea, support the differentiation from the grass isolates on the basis of phenotypic features (Palleroni, 1984; Hildebrand et al., 1994).

$P$. oryzihabitans, a yellow-pigmented bacterium that is closely related to the grass-associated isolate, can be distinguished from it by the ability to oxidize glucose and the absence of aesculin hydrolysis or lipases (Table 7). Furthermore, the composition of hydroxy fatty acids is a prominent feature. Analysis of cellular fatty acids of the grass isolates revealed the presence of 2hydroxydodecanoic acid (2-OH12:0) and 3-hydroxydodecanoic acid (3-OH12:0), as shown in Table 4. Strains of rRNA group I, including $P$. oryzihabitans, are characterized by the occurrence of fatty acids 3hydroxydecanoic acid (3-OH10:0) and 3-hydroxydodecanoic acid (3-OH12:0) (Oyaizu \& Komagata, 1983). Thus, the composition of hydroxy fatty acids are a useful feature for separating the grass isolates from most species of Pseudomonas sensu stricto.

So far, the phylogenetic and phenotypic comparison of the grass isolates particularly referred to Pseudomonas species for which rRNA-sequences were available. Species assigned to Pseudomonas in the Bacterial Nomenclature Up To Date (1998), edited by the DSMZ (home page http://www.dsmz.de/dsmzhome. html) which were not sequenced, can also be distinguished from the grass isolates. DNA-rRNA hybridization studies of the following species revealed that they belong to rRNA groups other than the 'authentic' Pseudomonas group I: Pseudomonas beteli, Pseudomonas boreopolis, Pseudomonas elongata, Pseudomonas hibisciola, Pseudomonas nautica, Pseudomonas pictorum (De Ley, 1991), Pseudomonas beijer- 
inckii (Kersters, 1991), Pseudomonas geniculata (Palleroni, 1991a), Pseudomonas huttiensis (Palleroni, 1984), Pseudomonas saccharophila (Palleroni, 1991b) and Pseudomonas woodsii (Schroth et al., 1991). The species Pseudomonas doudoroffii, Pseudomonas gelidicola and Pseudomonas halophila were described as halophilic marine bacteria, which can be easily distinguished by their requirements of $\mathrm{NaCl}$ for growth (Holt et al., 1994). Another group of species not sequenced so far can be characterized by its ability to produce a fluorescent pigment, or by the absence of a yellow pigment. Additionally, the distinction from the grass isolates is supported by several biochemical or chemotaxonomic features. This group incorporated the following species, which were able to fluoresce: Pseudomonas aurantiaca (Holt et al., 1994), Pseudomonas flectens (Johnson, 1956), Pseudomonas fuscovaginae (Miyajima et al., 1983), Pseudomonas monteilii (Elomari et al., 1997), Pseudomonas lundensis (Molin et al., 1986), Pseudomonas. savastanoi (Gardan et al., 1992), Pseudomonas veronii (Elomari et al., 1996), and species that were colourless or formed white colonies [Pseudomonas antimicrobica (Attafuah \& Bradbury, 1989), Pseudomonas carboxydohydrogena, Pseudomonas ficuserectae, Pseudomonas iners, Pseudomonas pertucinogena (Holt et al., 1994), Pseudomonas lanceolata (Leifson, 1962b), Pseudomonas meliae (Oigimi, 1977), Pseudomonas mephitica (Haynes \& Burkholder, 1957) and Pseudomonas spinosa (Leifson, 1962a)].

Thus, the grass isolates can be distinguished from all validly described Pseudomonas species on the basis of morphological, physiological and chemotaxonomic characteristics, and the results of $16 \mathrm{~S}$ rDNA sequence comparison, DNA-rRNA and DNA-DNA hybridization studies. Consequently, we conclude that the grass isolates deserve a separate species status, for which we propose the name Pseudomonas graminis sp. nov.

In Table 7 physiological and chemotaxonomical features of $P$. graminis are summarized, enabling a rapid differentiation of this new species from certain yellow-pigmented species, not necessarily closely phylogenetically related but characterized by high phenotypic similarity.

\section{Description of Pseudomonas graminis sp. nov.}

Pseudomonas graminis (gra'mi.nis. L. n. gramen grass, graminis of grass, the source of the organism).

Cells are Gram-negative, aerobic, non spore-forming, straight rods $(0.5-1.0$ by $3 \cdot 5-5.0 \mu \mathrm{m})$, motile, with one polar flagellum. Colonies are yellow, glistening, moderately convex and round with entire edges. Oxidasenegative, catalase-positive and unable to oxidize and ferment glucose. Does not produce fluorescent pigments on King medium B. Hydrolyses Tween 40 and 80 , aesculin, but not starch. It is negative for arginine dihydrolase, lysine decarboxylase, ornithine decarboxylase, tryptophan desaminase, DNase, urease and $\beta$-galactosidase. Voges-Proskauer reaction is negative. Does not produce indole or hydrogen sulphide. Reduction of nitrate to nitrite and denitrification is negative. $\beta$-Haemolysis of sheep blood is negative. Does not produce levan from sucrose. Nutritionally versatile. Substrates used by all strains are: adonitol, L-arabinose, D-arabitol, D-fructose, L-fucose, $\mathrm{D}$-galactose, $\alpha$-D-glucose, myo-inositol, D-mannitol, Dmannose, D-sorbitol, methylpyruvate, monomethyl succinate, cis-aconitic acid, citric acid, formic acid, Dgalactonic acid, D-galacturonic acid, D-gluconic acid, $\mathrm{D}$-glucosaminic acid, D-glucuronic acid, $\beta$-hydroxybutyric acid, itaconic acid, $\alpha$-ketoglutaric acid, D,Llactic acid, malonic acid, D-saccharic acid, succinic acid, bromosuccinic acid, succinamic acid, glucuronamide, D-alanine, L-alanine, L-alanylglycine, L-asparagine, L-aspartic acid, L-glutamic acid, L-histidine, L-proline, L-pyroglutamic acid, $\gamma$-aminobutyric acid, urocanic acid, inosine, uridine, 2-aminoethanol and glycerol. Substrates not used by any of the strains are: $N$-acetyl-D-galactosamine, $\quad N$-acetyl-D-glucosamine, cellobiose, $\mathrm{i}$-erythritol, gentiobiose, $\alpha$-D-lactose, lactulose, maltose, D-melibiose, $\beta$-methyl-D glucoside, Draffinose, $L$-rhamnose, sucrose, D-trehalose, $\gamma$-hydroxybutyric acid, $p$-hydroxyphenylacetic acid, quinic acid, sebacic acid, glycyl-L-aspartic acid, L-phenylalanine, thymidine, phenylethylamine, putrescine, 2,3-butanediol, glucose-1-phosphate, glucose-6-phosphate, $\alpha$ cyclodextrin, dextrin and glycogen. The $\mathrm{G}+\mathrm{C}$ content of the DNA is in the range $60-61 \mathrm{~mol} \%$. The major isoprenoid quinone is $\mathrm{Q}_{9}$. The major nonpolar fatty acids are hexadecanoic acid (16:0), hexadecenoic acid (16:1) and octadecenoic acid (18:1), and hydroxy fatty acids are 3-hydroxydodecanoic acid (3-OH12:0) and 2-hydroxydodecanoic acid (2-OH12:0). Isolated from the phyllosphere of grasses in Paulinenaue (Germany). The type strain is DSM $11363^{\mathrm{T}}\left(=\mathrm{P} 294 / 08^{\mathrm{T}}\right)$.

\section{ACKNOWLEDGEMENTS}

The authors wish to thank Mrs. B. Selch, Mrs. A. Nandke, Mrs. S. Weinert and Mrs. U. Mendrock for their excellent technical assistance. Further, they wish to thank Dr R. M. Kroppenstedt (Deutsche Sammlung von Mikroorganismen und Zellkulturen, Braunschweig) for special support to discuss hydroxy fatty acids. They also thank Dr R. J. Merry (Institute of Grassland and Environmental Research, Aberystwyth, UK) for advice in preparing the paper.

\section{REFERENCES}

Anzai, Y., Kudo, Y. \& Oyaizu, H. (1997). The phylogeny of the genera Chryseomonas, Flavimonas, and Pseudomonas supports synonymy of these three genera. Int J Syst Bacteriol 47, 249-251.

Azegami, K., Nishiyama, K., Watanabe, Y., Kadota, I., Ohuchi, A. \& Fukazawa, C. (1987). Pseudomonas plantarii sp. nov., the causal agent of rice seedling blight. Int $J$ Syst Bacteriol 37, 144-152.

Attafuah, A. \& Bradbury, J. F. (1989). Pseudomonas antimicrobica, a new species strongly antagonistic to plant pathogens. J Appl Bacteriol 67, 567-573.

Behrendt, U., Müller, T. \& Seyfarth, W. (1997). The influence of 
extensification in grassland management on the populations of micro-organisms in the phyllosphere of grasses. Microbiol Res 152, 75-85.

De Ley, J. (1991). The proteobacteria: ribosomal RNA cistron similarities and bacterial taxonomy. In The Prokaryotes, 2nd edn, vol. II, pp. 2111-2140. Edited by A. Balows and others. Berlin: Springer-Verlag.

Elomari, M., Coroler, L., Hoste, B., Gillis, M., Izard, D. \& Leclerc, H. (1996). DNA relatedness among Pseudomonas strains isolated from natural mineral waters and proposal of Pseudomonas veronii sp. nov. Int J Syst Bacteriol 46, 1138-1144.

Elomari, M., Coroler, L., Verhille, S., Izard, D. \& Leclerc, H. (1997). Pseudomonas monteilii sp. nov., isolated from clinical specimens. Int $J$ Syst Bacteriol 47, 846-852.

Ercolani, G. L. (1991). Distribution of epiphytic bacteria on olive leaves and the influence of leaf age and sampling time. Microb Ecol 21, 35-48.

Gardan, L., Bollet, C., Abu Ghorrah, M., Grimont, F. \& Grimont, P. A. D. (1992). DNA relatedness among the pathovar strains of Pseudomonas syringae subsp. savastanoi Janse (1982) and proposal of Pseudomonas savastanoi sp. nov. Int J Syst Bacteriol 42, 606-612.

Gilardi, G. L. (1991). Pseudomonas and related genera. In Manual of Clinical Microbiology, 5th edn, pp. 429-453. Edited by A. Balows and others. Washington, DC: American Society for Microbiology.

Groth, I., Schumann, P., Weiss, N., Martin, K. \& Rainey, F. A. (1996). Agrococcus jenensis gen. nov., sp. nov., a new genus of actinomycetes with diaminobutyric acid in the cell wall. Int $J$ Syst Bacteriol 46, 234-239.

Haynes, W. C. \& Burkholder, W. H. (1957). Genus I Pseudomonas Migula 1894. In Bergey's Manual of Determinative Bacteriology, 7th edn, pp. 89-152. Edited by R. S. Breed, E. G. D. Murray \& N. R. Smith. Baltimore: Williams \& Wilkins.

Hildebrand, D. C., Palleroni, N. J., Hendson, M., Toth, J. \& Johnson, J. L. (1994). Pseudomonas flavescens sp. nov., isolated from Walnut blight cankers. Int J Syst Bacteriol 44, 410-415.

Hirano, S. S. \& Upper, C. D. (1992). Bacterial community dynamics. In Microbial Ecology of Leaves, pp. 271-294. Edited by J. H. Andrews \& S. S. Hirano. New York: Springer.

Holmes, B., Owen, R. J., Evans, A., Malnick, H. \& Wilcox, W. R. (1977). Pseudomonas paucimobilis, a new species isolated from human clinical specimens, the hospital environment, and other sources. Int J Syst Bacteriol 27, 133-146.

Holmes, B., Pinning, C. A. \& Dawson, C. A. (1986). A probability matrix for the identification of Gram-negative bacteria that grow on nutrient agar. $J$ Gen Microbiol 132, 1827-1842.

Holmes, B., Steigerwalt, A. G., Weaver, R. E. \& Brenner, D. J. (1987). Chryseomonas luteola comb. nov. and Flavimonas oryzihabitans gen. nov., comb. nov., Pseudomonas-like species from human clinical specimens and formerly known, respectively, as groups Ve-1 and Ve-2. Int J Syst Bacteriol 37, 245-250.

Holt, J. G., Krieg, N. R., Sneath, P. H. A., Staley, J. T. \& Williams, S. T. (editors) (1994). Bergey's Manual of Determinative Bacteriology, 9th edn. Baltimore: Williams \& Wilkins.

Hugh, R. \& Leifson, E. (1953). The taxonomic significance of fermentative versus oxidative metabolism of carbohydrates by various Gram-negative bacteria. J Bacteriol 66, 24-26.

Johnson, J. (1956). Pod twist: a previously unrecorded bacterial disease of French bean (Phaseolus vulgaris L.). Qld J Agric Sci 13, 127-158.

Kersters, K. (1991). The genus Deleya. In The Prokaryotes, 2nd edn, vol. IV, pp. 3189-3197. Edited by A. Balows and others. Berlin: Springer-Verlag.

King, E. O., Ward, M. K. \& Raney, D. E. (1954). Two simple media for the demonstration of pyocyanin and fluorescin. $J$ Lab Clin Med 44, 301-307.

Legard, D. E., McQuilken, M. P., Whipps, J. M., Fenlon, J. S., Fermor, T. R., Thompson, I. P., Bailey, M. J. \& Lynch, J. M. (1994). Studies of seasonal changes in the microbial populations on the phyllosphere of spring wheat as a prelude to the release of a genetically modified microorganism. Agric Ecosyst Environ 50, 87-101.

Leifson, E. (1962a). Pseudomonas spinosa n. sp. Int Bull Bacteriol Nomencl Taxon 12, 88-92.

Leifson, E. (1962b). The bacterial flora of distilled and stored water. III. New species of the genera Corynebacterium, Flavobacterium, Spirillum and Pseudomonas. Int Bull Bacteriol Nomencl Taxon 12, 161-170.

Martin, K., Schumann, P., Rainey, F. A., Schuetze, B. \& Groth, I. (1997). Janibacter limosus gen. nov., sp. nov., a new actinomycete with meso-diaminopimelic acid in the cell wall. Int J Syst Bacteriol 47, 529-534.

Miyajima, K., Tanii, A. \& Akita, T. (1983). Pseudomonas fuscovaginae sp. nov., nom. rev. Int J Syst Bacteriol 33, 656-657.

Molin, G., Ternström, A. \& Ursing, J. (1986). Pseudomonas lundensis, a new bacterial species isolated from meat. Int J Syst Bacteriol 36, 339-342.

Oigimi, C. (1977). Studies on bacterial gall of Chinaberry (Melia Azedarach Lin.), caused by Pseudomonas meliae n. sp. Bull Coll Agric Univ Ryukyus 24, 497-556.

Oyaizu, H. \& Komagata, K. (1983). Grouping of Pseudomonas species on the basis of cellular fatty acid composition and the quinone system with special reference to the existence of 3hydroxy fatty acids. J Gen Appl Microbiol 29, 17-40.

Palleroni, N. J. (1984). Genus I. Pseudomonas Migula 1894, $237^{\mathrm{AL}}$ (Nom. cons. Opin. 5, Jud. Comm. 1952, 237). In Bergey's Manual of Systematic Bacteriology, vol. 1, pp. 141-199. Edited by N. R. Krieg \& J. G. Holt. Baltimore: Williams \& Wilkins.

Palleroni, N. J. (1991a). Introduction to the family Pseudomonadaceae. In The Prokaryotes, 2nd edn, vol. III, pp. 3071-3085. Edited by A. Balows and others. Berlin: Springer-Verlag.

Palleroni, N. J. (1991b). Human- and animal-pathogenic pseudomonads. In The Prokaryotes, 2nd edn, vol. III, pp. 3086-3103. Edited by A. Balows and others. Berlin: SpringerVerlag.

Palleroni, N. J. (1992). Present situation of the taxonomy of aerobic pseudomonads. In Pseudomonas: Molecular Biology and Biotechnology, pp. 105-115. Edited by E. Galli, S. Silver \& B. Witholt. Washington, DC: American Society for Microbiology.

Palleroni, N. J. \& Bradbury, J. F. (1993). Stenotrophomonas, a new bacterial genus for Xanthomonas maltophilia (Hugh 1980) Swings et al. 1983. Int J Syst Bacteriol 43, 606-609.

Palleroni, N. J., Kunisawa, R., Contopoulou, R. \& Doudoroff, M. (1973). Nucleic acid homologies in the genus Pseudomonas. Int $J$ Syst Bacteriol 23, 333-339.

Pollock, T. J. (1993). Gellan-related polysaccharides and the genus Sphingomonas. J Gen Microbiol 139, 1939-1945.

Prauser, H. \& Falta, R. (1968). Phagensensibilität, ZellwandZusammensetzung und Taxonomie von Actinomyceten. $Z$ Allg Mikrobiol 8, 39-46.

Rudolph, K. \& Marvidis, A. (1990). Flagella, motility, chemotaxis 
and helicity. In Methods in Phytobacteriology, pp. 441-444. Edited by Z. Klement, K. Rudolph \& D. C. Sands. Budapest: Akademiai Kiado.

Rudolph, K., Roy, M. A., Sasser, M., Stead, D. E., Davis, D. E., Swings, M. \& Gosselé, F. (1990). Isolation of bacteria. In Methods in Phytobacteriology, pp. 43-86. Edited by Z. Klement, K. Rudolph \& D. C. Sands. Budapest: Akademiai Kiado.

Ryu, E. (1938). On the Gram-differentiation of bacteria by the simplest method. J Jpn Soc Vet Sci 17, 58-63.

Saitou, N. \& Nei, M. (1987). The neighbor-joining method: a new method for reconstructing phylogenetic trees. Mol Biol Evol 4, 406-425.

Schaad, N. W. \& Stall, R. E. (1994). Xanthomonas. In Laboratory Guide for Identification of Plant Pathogenic Bacteria, 2nd edn, pp. 81-94. Edited by N. W. Schaad. St Paul, MN: American Phytopathological Society Press.

Schroth, M. N., Hildebrand, D. C. \& Panopoulos, N. (1991). Phytopathogenic pseudomonads and related plant-associated pseudomonads. In The Prokaryotes, 2nd edn, vol. III, pp. 3104-3131. Edited by A. Balows and others. Berlin: SpringerVerlag.

Segers, P., Vancanneyt, M., Pot, B., Torck, U., Hoste, B., Dewettinck, D., Falsen, E., Kersters, K. \& De Vos, P. (1994). Classification of Pseudomonas diminuta Leifson and Hugh 1954 and Pseudomonas vesicularis Büsing, Döll, and Freytag 1953 in Brevundimonas gen. nov. as Brevundimonas diminuta comb. nov. and Brevundimonas vesicularis comb. nov., respectively. Int $J$ Syst Bacteriol 44, 499-510.

Smibert, R. M. \& Krieg, N. R. (1994). Phenotypic characterization. In Methods for General and Molecular Bacteriology, pp. 607-655. Edited by P. Gerhardt, R. G. E. Murray, W. A. Wood \& N. R. Krieg. Washington, DC: American Society for Microbiology.

Stackebrandt, E. \& Goebel, B. M. (1994). Taxonomic note: a place for DNA-DNA reassociation and 16S rRNA sequence analysis in the present species definition in bacteriology. Int $J$ Syst Bacteriol 44, 846-849.

Starr, M. P., Jenkins, C. L., Bussy, L. B. \& Andrewes, A. G. (1977). Chemotaxonomic significance of the xanthomonadins, novel brominated aryl-polyene pigments produced by bacteria of the genus Xanthomonas. Arch Microbiol 113, 1-9.

Stead, D. E. (1988). Identification of bacteria by computerassisted fatty acid profiling. Acta Hortic 225, 39-46.

Süßmuth, R., Eberspächer, J., Haag, R. \& Springer, W. (1987). Biochemisch-mikrobiologisches Praktikum. Stuttgart \& New York: Thieme.

Tamaoka, J., Ha, D.-M. \& Komagata, K. (1987). Reclassification of Pseudomonas acidovorans den Dooren de Jong 1926 and Pseudomonas testosteroni Marcus and Talalay 1956 as
Comamonas acidovorans comb. nov. and Comamonas testosteroni comb. nov., with an emended description of the genus Comamonas. Int J Syst Bacteriol 37, 52-59.

Thompson, I. P., Bailey, M. J., Fenlon, J. S. \& 8 other authors (1993). Quantitative and qualitative seasonal changes in the microbial community from the phyllosphere of sugar beet (Beta vulgaris). Plant Soil 150, 177-191.

Thornley, M. J. (1960). The differentiation of Pseudomonas from other Gram-negative bacteria on the basis of arginine metabolism. J Appl Bacteriol 23, 37-52.

Tindall, B. J. (1990). Lipid composition of Halobacterium lacusprofundi. FEMS Microbiol Lett 66, 199-202.

Ulrich, A. \& Muller, T. (1998). Heterogeneity of plant-associated streptococci as characterized by phenotypic features and restriction analysis of PCR-amplified 16S rDNA. J Appl Microbiol 84, 293-303.

Van Landschoot, A., Rossau, R. \& De Ley, J. (1986). Intra- and intergeneric similarities of the ribosomal ribonucleic acid cistrons of Acinetobacter. Int J Syst Bacteriol 36, 150-160.

Weisburg, W. G., Barns, S. M., Pelletier, D. A. \& Lane, D. J. (1991). 16S ribosomal DNA amplification for phylogenetic study. $J$ Bacteriol 173, 697-703.

Willems, A., Busse, J., Goor, M. \& 8 other authors (1989). Hydrogenophaga, a new genus of hydrogen-oxidizing bacteria that includes Hydrogenophaga flava comb. nov. (formerly Pseudomonas flava), Hydrogenophaga palleronii (formerly Pseudomonas palleronii), Hydrogenophaga pseudoflava (formerly Pseudomonas pseudoflava and 'Pseudomonas carboxyflava'), and Hydrogenophaga taeniospiralis (formerly Pseudomonas taeniospiralis). Int J Syst Bacteriol 39, 319-333.

Willems., A., Falsen, E., Pot, B., Jantzen, E., Hoste, B., Vandamme, P., Gillis, M., Kersters, K. \& De Ley, J. (1990). Acidovorax a new genus for Pseudomonas facilis, $P$. delafieldii, EF group 13, EF group 16, and several clinical isolates, with the species Acidovorax facilis comb. nov., Acidovorax delafieldii comb. nov. and Acidovorax temperans sp. nov. Int J Syst Bacteriol 40, 384-398.

Yabuuchi, E., Yano, I., Oyaizu, H., Hashimoto, Y., Ezaki, T. \& Yamamoto, H. (1990). Proposals of Sphingomonas paucimobilis gen. nov. and comb. nov., Sphingomonas parapaucimobilis sp. nov., Sphingomonas yanoikuyae sp. nov., Sphingomonas adhaesiva sp. nov., Sphingomonas capsulata comb. nov., and two genospecies of the genus Sphingomonas. Microbiol Immunol 34, 99-119.

Yabuuchi, E., Kosako, Y., Oyaizu, H., Yano, I., Hotta, H., Hashimoto, Y., Ezaki, T. \& Arakawa, M. (1992). Proposal of Burkholderia gen. nov. and transfer of seven species of the genus Pseudomonas homology group II to the new genus, with the type species Burkholderia cepacia (Palleroni and Holmes 1981) comb. nov. Microbiol Immunol 36, 1251-1275. 